\begin{tabular}{|l|c|}
\hline \multicolumn{2}{|c|}{ Toppan Best-set Premedia Limited } \\
\hline Journal Code: BJPI & Proofreader: Mony \\
\hline Article No: BJPI537 & Delivery date: 02 Aug 2012 \\
\hline Page Extent: 12 & \\
\hline
\end{tabular}

\title{
Introduction: Interpreting British Foreign Policy
}

\author{
Mark Bevir, Oliver Daddow and Ian Hall
}

This special issue collects together a series of essays that investigate the analytical possibilities offered to the study of British foreign policy by the interpretive approach to political science and international relations. The interpretive approach concentrates on the beliefs of various policy actors, the meanings of their actions, and, crucially, explains the beliefs by locating them in historical traditions and as responses to dilemmas. It highlights the contingency, diversity, and contestability of the beliefs, narratives, and expertise that inform political action. This interpretive approach is widespread in the study of governance and domestic policy (Bevir and Rhodes 2003, 2006 and 2010; Bevir et al. 2003; Dudley 2003; Richards and Smith 2004; Irazabal 2005; Orr 2005, 2009; Craig 2006; Monro 2006; Morrell 2006; Stoker 2006; Bevir and Trentmann 2007; Clark and Gains 2007; Finlayson 2008; Jose 2007; Rhodes et al. 2007; Sullivan 2007; Yi-Chong and Weller 2007; Bache and Catney 2008; Dinham and Lowndes 2008; Wood et al. 2008; Bevir and Richards 2009; O'Brien et al. 2009; Orr and Vince 2009; Bevir 2010; Booth 2010; Edwards 2011; Kenny 2010; Krueger and Gibbs 2010; Richards and Mathers 2010; and for earlier critical discussions in this journal see Finlayson 2004; Marsh 2008).

However, the interpretive approach has not yet had much impact on studies of foreign policy (but see Beech 2011; Bratburg 2011; Daddow and Gaskarth 2011). This special issue addresses that omission. It focuses on the traditions and dilemmas that have shaped British foreign policy in the post-Cold War period.

\section{The Practice of Foreign Policy}

British foreign policy has never been immune from 'external' influences-from public opinion and the press, for example, or commercial interest—but today it is a far messier practice than it once was. Two developments, in particular, have been responsible for increasing the sense of messiness in British foreign policy. The first is the erosion of the influence of the Foreign and Commonwealth Office (FCO) and the emergence of a range of other actors (domestic and external; state and non-state) which impact upon foreign policy-making. The second is the increasing complexity of the areas in which British foreign policy is conducted following the rise of devolution, the European Union (EU), and global governance. Ministries and agencies across government now routinely conduct relations with counterparts in other European states and states outside the EU. Prime ministers engage in telephone diplomacy with other leaders; finance, defence, environment and other ministers hold regular meetings with their equivalents overseas. Sometimes officials from the FCO play a role in these contacts, but often they do not. Foreign policymaking and implementation is thus fragmented, and the lines between domestic 
and foreign policy have become blurred, with many issues and challenges cutting across familiar departmental demarcations.

Nowhere are the changes in the practice of foreign policy more obvious than in Europe. The removal of the threat of force from European international relations has transformed diplomacy proper into 'politics' (Keens-Soper 1999). But the manner in which matters are dealt with is also significant. While high-level issues such as defence and international security largely remain the preserve of leaders and ministers and are settled in forums that more resemble multilateral summits than parliaments, most lower-level issues are negotiated by officials or simply decided upon by Brussels-based bureaucrats or politicians.

The blurring of domestic and foreign policy, of politics and diplomacy, is not confined to Europe. It has spread with the new practices of global governance that have emerged in the post-Cold War era (Bevir and Hall 2011). International rules and standards are sometimes now set by private authorities (Hall and Biersteker 2002). Transnational networks of scholars, businesspeople, think-tanks and nongovernmental organisations (NGOs) shape policy responses to global challenges. To address these issues, foreign policy-makers have also turned to new practices and techniques derived from social scientific theories-new 'rationalities' (Bevir and Hall 2011, 359-362). These rationalities have been used to change the institutions of government, to draw new actors into policy-making processes, and to justify new modes of work.

British foreign policy is thus being made and implemented in significant new ways. The centralisation of decision-making in British government has resulted in greater involvement in policy-making by the Prime Minister's Office and more oversight of diplomacy being performed by the Treasury (Williams 2004). Internal reforms to the FCO have attempted to transform it from a repository of expertise and a source of policy advice to a 'network actor' designed to facilitate the implementation of decisions made elsewhere (see Hall 2013). Parallel reforms to other ministries have given them new channels to the outside world. For example, European departments and sustainability divisions now coordinate internal working with global climate policy.

All of these changes have occurred as the role of British foreign policy and the place of Britain in the world have been redefined. At the start of the post-Cold War era, Britain was often perceived as a principally European power, albeit one with a cherished 'special relationship' with the US and increasing attenuated ties to the Commonwealth. Its military forces made a major contribution to the defence of Europe and British overseas territories, but were not considered to have a wider role. Under John Major, but especially under Tony Blair and New Labour (see Daddow and Gaskarth 2011), these beliefs were set aside as Britain was reinvented as a global power fit for an age of globalisation and humanitarian intervention.

\section{The Study of Foreign Policy}

While the practice of foreign policy is rapidly changing, mainstream scholarship on the subject has largely stood still. Foreign policy analysis continues to appeal to capabilities, structural determinants, or the attributes of leaders to explain why 
states behave as they do. There are surprisingly few attempts to explore either the increasing messiness of policy making or the diverse actors involved with their varying beliefs and desires. The focus remains on reified capacities and structures or on the 'operational codes' or psychologies of leaders. Realists argue that foreign policy is a function of the distribution of capabilities - that all states seek power, that strong states aim either for a stable balance of power between great powers or for hegemony, and that weak states ally or bandwagon depending on which gains them security (Waltz 1979; Walt 1990; Rose 1998; Mearsheimer 2001). Marxists maintain that foreign policy is driven not by the distribution of military capabilities but by the material logics of global capitalism (Wallerstein 2004). By contrast, institutionalists concentrate on other kinds of structural constraints, notably constitutional forms, bureaucratic politics or organizational processes (Allison 1971; Fioretos 2011). Lastly, some analysts of foreign policy have focussed on the 'belief systems', 'operational codes', 'national role conceptions', or the psychologies of individuals (George 1969; Jervis 1976; Hermann 1980; Goldstein and Keohane 1993; Larson 1994).

The study of British foreign policy has tended to concentrate more on institutional and personal factors, with the occasional nod toward material capabilities as background enablers or constraints. The traditional approach remains a historical one, normally narrating the actions of Prime Ministers and their governments and explaining them in terms of the interaction between political preferences and material capabilities (Northedge 1961; Reynolds 2000). But studies using different approaches can also be found. There are a number of analytical studies of the institutional arrangements of the foreign policy-making apparatus (Beloff 1955; Frankel 1963; Jones 1974). These studies offer institutional or structural explanations for foreign policy formulation and implementation grounded in modernist empiricist social science.

While mainstream foreign policy analysis may appear to have stood still, recent years have seen the rise of various constructivist, critical and poststructural approaches in the subfield of International Relations that have spilled over into studies of foreign policy. These emphasise the role of identities and discourses in shaping foreign policy preferences. Constructivists have alighted on conceptions of national identity and on the effects of norms on political behaviour. They argue that inter-subjectively generated ideas and norms rather than capabilities and institutions shape foreign policy behaviour (Onuf 1989; Wendt 1992, 1994, 1999; Katzenstein 1996a, 1996b; Weldes 1996, 1999; Laffey and Weldes 1997; Finnemore and Sikkink 1999; Risse et al. 1999). Critical theorists and poststructuralists, by contrast, concentrate on the deconstructions of discourses that they argue form the background to foreign and security policy decision-making (Campbell 1998; McDonald 2005; Fierke 2007; Burke 2008; Bulley 2009).

These approaches are concerned with interpreting the meaning of identities and discourses, but-like earlier studies of 'belief systems' and 'operational codes'commonly appeal to structures to explain why political actors behave as they do. Constructivists recognise that identities and norms are generated inter-subjectively, but often imply that once they are generated, they function as constraints or even as determinants of political behaviour (Wendt 1987, 1995; Carlsnaes 1992). Critical 
theorists also argue that social structures determine behaviour, but in many cases they also appeal—at least implicitly—to materialist explanations of political action. Robert Cox's oft-quoted observation that ' $[\mathrm{t}]$ heory is always for someone and for some purpose' (Cox 1996) illustrates this well, signalling a Gramscian belief that the content of hegemonic discourses indicate particular relationships of material power. For many critical theoretical and poststructural students of foreign policy, deconstructing dominant discourses is a means of exposing these underlying structures (George and Campbell 1990; Doty 1996).

The rise of constructivism, critical theory and poststructuralism in foreign policy analysis has thus led to the use of interpretive methods but not, we argue, to a thorough-going interpretive approach.

\section{The Interpretive Approach}

The interpretive approach often runs parallel to the constructivist and poststructuralist approaches that are increasingly common in the study of foreign policy. Crucially, the rise of constructivism and poststructuralism has brought greater attention to meanings and the ways ideas, norms and discourses shape policy. Further, constructivists and poststructuralists often explicitly reject the positivism that informs much realism and institutionalism. They argue that positivism rests on the erroneous philosophical idea that knowledge of the world can come from pure reason or pure experience. They insist instead that knowledge is always mediated by beliefs and languages. Again, norms and discourses crucially shape the ways in which people approach foreign policy problems.

Although the interpretive approach echoes constructivism and poststructuralism in eschewing positivism and focusing on meanings, it also differs from them (Bevir and Rhodes 2010, 25-80). The interpretive approach is avowedly humanist and historicist, emphasising agency rather than structure. In contrast, constructivism often remains wedded to formal modernist explanations, and poststructuralism often contains strong residues of anti-humanism. Interpretivists thus worry that constructivism and poststructuralism still remain tied to reified ontologies and formal explanations. It is true that constructivists and poststructuralists rarely discuss these issues explicitly, and when they challenged on them, they sometimes pay lip-service to the humanist and historicist orientation of the interpretive approach. Nonetheless, even when they pay lip-service to humanist and historicist ideas, they typically drift towards reified ontologies and formal explanations. Thin constructivists treat 'ideas' as variables alongside 'interests', thus gesturing towards formal explanations based on correlations between variables and outcomes (Keohane 1988; Goldstein and Keohane 1993). Thick constructivists treat ideas differently, seeing them as constitutive of social structures that shape and sometimes even determine behaviour (Wendt 1999). And despite their name, poststructuralists treat discourses as reified entities that are defined by the relations among units or signs, not as products of the activity of individuals.

Interpretivists do not necessarily deny the existence of institutions, fields, power/ knowledge, or discourses. They recognize that there are patterns in contingent human activity, and there is nothing intrinsically wrong about calling these patterns 
'institutions' or 'discourses'. The issue is whether these patterns explain anything. Even when constructivists and poststructuralists acknowledge the importance of ideas and agency, they are still tempted to ascribe explanatory power to institutions and discourses. They thus drift towards reification and determinism. They begin to reject humanist and historicist explanations for formal ones. Their explanations appeal to the alleged logic of institutions or the internal relations among the signs of a discourse.

The interpretive approach thus favours aggregate concepts that clearly reflect a humanist and historicist perspective. They conceive of individuals not as the passive supports of institutions or discourses but as agents who can modify inherited norms and languages for reasons of their own. Equally, interpretivists conceive of agency as inherently situated. Agency always occurs against a particular historical background that influences it (for example Daddow 2011). Interpretivists thus explain actions and practices by reference to traditions and dilemmas. A tradition captures the historical inheritance against the background of which individuals act. A dilemma captures the way people are capable of modifying this inheritance to incorporate novel experiences or ideas.

Appeals to tradition are the counterpart of situated agency. People are not autonomous, so their agency is always situated against an inherited web of beliefs and practices. Their beliefs and actions draw on an inherited tradition. The idea of a tradition captures the social context in which individuals both exercise their reason and act. Here, traditions are defined as a set of understandings someone receives during socialisation. So conceived, tradition is unavoidable only as a starting point, not as something that determines later performances. Later performances are products of creative, situated agency in the setting of tradition. It is therefore important to be cautious about representing tradition as an unavoidable presence in everything people do and, in so doing, underplay the role for situated agency. In particular, it should not be implied that tradition is constitutive of the beliefs people later come to hold or the actions they come to perform. Instead, tradition should be seen mainly as a first influence on people. The content of the tradition will appear in their later actions, only if their situated agency has not led them to change it, and every part of it is in principle open to such change.

\section{The Traditions of British Foreign Policy}

Domestic politics in Britain has been influenced by a number of different political, cultural, and social scientific traditions, and foreign policy is no different. The most discussed political traditions are the conservative, whig, liberal and socialist ones, all of which contend in British foreign policy (Hall 2012). The conservative tradition emphasises the need for scepticism and prudence in international affairs, arguing that the cautious pursuit of state interests is the preferable strategy (Hall and Rengger 2005). The whig tradition is equally suspicious of moralism, but is more confident in the ability of British diplomacy effectively to influence international relations, opening a space for ethical considerations to shape British policy (Hall 2006, 117-123). By contrast, liberals and socialists privilege internationalist themes. The liberal tradition calls for a foreign policy driven by an unflinching devotion to cosmopolitan ethics, economic freedom, strong international law and the institutions to 
enforce it, and the extension of liberal democratic forms of government. Socialists share the cosmopolitanism and internationalism of liberals, but depart from them on the virtues of free markets and liberal-as opposed to social-democracy. They profess faith in international institutions, but often lament their apparent inadequacy when dealing with international issues of socialist concern.

These political traditions have evolved and changed over time as their inheritors have responded to various dilemmas. Moreover, it has rarely been the case that one tradition alone has shaped a government's foreign policy. Rather, as the New Labour governments demonstrated so well after 1997, the making and conduct of foreign policy is normally shaped by the interaction of different traditions. Under New Labour, inheritors of a more liberal socialism such as Tony Blair vied with social democrats such as Robin Cook, as well as with the whiggish (and occasionally conservative) denizens of the FCO, the wider Civil Service and the military. To varying degrees, they sought to appropriate aspects of those traditions that they saw as useful in particular circumstances, or indeed to redefine what they thought was old-fashioned or inappropriate. Blair's blending of a Gladstonian concern with human rights with a more contemporary account of the transformations wrought to international relations by globalization well illustrates this mode of renegotiating traditions in response to new ideas.

As we shall see, the post-Cold War period saw extensive renegotiations of this kind. For most of the past century, the whig tradition has been dominant in British foreign policy making, held dear by British diplomats in particular. In the 1990s, however, the rise of new ways of thinking about and practising governance began to challenge the whig ascendency and erode the claim that government was best practised by a bureaucratic elite claiming exclusive expertise over their domain. Whiggism was transformed from a narrative of rule to one of resistance. So too was conservatism, which had returned to British foreign policy in a particularly desiccated form during Douglas Hurd's tenure at the FCO (1989-95). The Balkan wars and humanitarian emergencies elsewhere in the world posed multiple dilemmas for the adherents of a tradition that appeared out-dated in the contemporary world, and they struggled to respond effectively as liberals and socialists quickly adapted to the new circumstances (Hall and Rengger 2005).

These political traditions are cross-cut with other prominent cultural traditions. The three most obvious cultural traditions are: Atlanticism, pro-Europeanism, and pro-Commonwealth ideas-traditions that may occur alongside the beliefs of all four political traditions. Where the Atlanticists prefer Britain to lean towards the United States, the pro-Europeans wish for deeper commitment to the EU. The pro-Commonwealth tradition, which calls for British foreign policy to take more seriously its ties to former imperial possessions and dominions, attracts far fewer adherents today than it did in the 1950s and 1960s, but resurfaces periodically, especially among conservatives (Hague 2011). As with the political traditions, inheritors of these sets of beliefs vary when it comes to their views on particular issues. Atlanticists, for example, may conceive their proper role-and the proper role for Britain-as standing 'shoulder-to-shoulder' with the United States or as constructive critics (Dunne 2004). Similarly, Europeanists may argue that the preferable strategy is accepting the unpalatable even if it runs counter to short-term 
interests or they may contend that Europe is better served by British-led opposition to certain initiatives in Brussels (Daddow 2004).

Finally, there are also those traditions that are derive from social scientific work on international relations and which practitioners inherit either directly (normally in higher education) or indirectly (from think-tanks, NGOs or the media). The major social scientific traditions are realism, internationalism, various kinds of Marxism and post-Marxism, and feminism. These traditions too may be detected in the thought of particular individuals involved with the formulation and implementation of British foreign policy. They underpin and inform a series of more technical aspects of policy making, what we call 'rationalities'. These rationalities are taken up and utilised by practitioners when faced by dilemmas that conventional approaches seem to be unable to solve. The use of networks rather than traditional bureaucracies for resource allocation and service delivery offers one example of a rationality.

\section{Interpreting British Foreign Policy}

The articles in this special issue examine aspects of British foreign policy in the post-Cold War period and assess the merits of the interpretive approach. Not all of them agree wholeheartedly that the interpretive approach is the best way forward, but they all engage with what it offers students of international relations. They all focus on the beliefs of policy actors, locating them against the background of different traditions and dilemmas.

The first three articles—by Judi Atkins, Jamie Gaskarth and Oliver Daddowexamine the evolution of key traditions in the beliefs of policymakers. Judi Atkins' opening article examines New Labour's renegotiation of elements of the social democratic tradition in response to the perceived demands of globalization. She argues that New Labour drew upon interdependence theory, neocommunitarianism and democratic peace theory to re-cast social democratic internationalism to confront a series of new dilemmas. While this renegotiation was contested, it helps to explain the apparent contradictions in Tony Blair's foreign policy.

Jamie Gaskarth's focus is also on the beliefs and perceptions of policymakers and the ways in which these are modified in response to new dilemmas. His article draws upon extensive interviews with ten ministers charged with responsibility for foreign policy between 1977 and 2010. His concern is how the interviewees themselves conceived the traditions they believed shaped British foreign policy during that period, how they drew upon the resources they offered to confront ethical dilemmas and how they re-shaped those traditions as a consequence. In particular, his article points to the persistence of the 'whig' tradition, despite the rise of the kind of new thinking Atkins describes.

In his article, Oliver Daddow also takes the longer view, exploring the reformation of Euroscepticism at the hands of Margaret Thatcher and Tony Blair. Rather than seeing Euroscepticism as a 'structuring' discourse, as some do, Daddow argues that Blair came to share many of the same beliefs as Thatcher espoused in the latter part of her Prime Ministership. 
Ian Hall's article turns from traditions to rationalities. The reform of the Foreign and Commonwealth Office (FCO) until New Labour is often thought to be driven by ideology, especially socialist hostility to perceived conservatism. Hall tells a more complex story, arguing that the reform process was driven by a number of different sets of beliefs, including demands from within the FCO itself for greater openness and accountability both to its own staff and to external stakeholders. These various demands were met by the introduction of new rationalities drawn especially from 'new public management' (NPM) and network theories, as well as from social scientific ideas concerning the relationship between identity and policy-making.

The last four articles deal with particular dilemmas in recent British foreign policy: humanitarian intervention, militant Islamist terrorism, Turkey's membership negotiations with the EU, and the challenge posed to the nuclear order by Iran. David McCourt argues that neither the advent of an 'ethical foreign policy' nor the beliefs and mind-set of Tony Blair are sufficient to explain the shift towards a more interventionist foreign policy in the late 1990s. Instead, he argues that a revival and renegotiation of the Atlanticist tradition in New Labour best explains the decision taken to push for intervention in Kosovo in 1998-99 and the abandonment of earlier realist approaches to the break-up of Yugoslavia.

In his article, Steven Kettell seeks to fuse elements of interpretivism and postmodern approaches to examine the discourse used by New Labour-and by Tony Blair in particular-to try to legitimate British involvement in the 'War on Terror'. Kettell's focus is the emergence, use and destabilisation of what he calls 'discursive strategies' - how they develop in response to dilemmas and how they are utilised by political actors to justify political actions.

In his account of the treatment by the British press of the question of Turkish accession to the EU, Ryan Philips turns from the foreign policy making elite to the role played by media. He argues that the election of the Islamist Justice and Development Party (AKP) in 2007 prompted a significant renegotiation of inherited beliefs about the possibility of Turkish EU membership, as earlier, positive views were replaced by more sceptical attitudes.

In the last article, Chris Kitchen and Rhiannon Vickers return to the tensions between New Labour's internationalist inheritance and the new dilemmas they faced. They argue that Iran posed a significant challenge to the pursuit of an internationalist foreign policy, confronting successive New Labour governments with problems not easily resolved by internationalist means. Their article tracks the twists and turns of British policy on Iran's nuclear program, showing how policy initiatives were formulated, implemented and tested in practice, as core beliefs in the minds of policymakers about how international relations ought to work were subjected to the pressures of events.

\section{About the Authors}

Mark Bevir, Department of Political Science, University of California, 210 Barrows Hall \#1950, Berkeley, CA 94720-1950, California, USA, email: mbevir@berkeley.edu

Oliver Daddow, Department of Politics and International Relations, University of Leicester, University Road, Leicester LE1 7RH, UK, email: od21@leicester.ac.uk 
JOBNAME: No Job Name PAGE: 9 SESS: 10 OUTPUT: Thu Aug 2 19:14:40 2012 SUM: EE14F2E7

/v2501/blackwell/B_journals/bjpi_v0_i0/bjpi_537

Ian Hall, Department of International Relations, Australian National University, Hedley Bull Centre, Canberra, ACT 2022, Australia, email: ian.hall@anu.edu.au

\section{Note}

The authors would like to thank the Center for British Studies, University of California, Berkeley for hosting the workshop from which this special issue was derived.

\section{References}

Allison, G. T. (1971) Essence of Decision: Explaining the Cuban Missile Crisis (New York: Little, Brown \& Co).

Bache, I. and Catney, P. (2008) 'Embryonic associationalism: New Labour and urban governance', Public Administration, 86:2, 411-428.

Beech, M. (2011) 'British conservatism and foreign policy: Traditions and ideas shaping Cameron's global view', British Journal of Politics and International Relations, 13:3, 348-363.

Beloff, M. (1955) Foreign Policy and the Democratic Process (Baltimore, MD: Johns Hopkins University Press). Bevir, M. (2010) Democratic Governance (Princeton, NJ: Princeton University Press).

Bevir, M and Hall, I. (2011) 'Global governance', in M. Bevir (ed.), The Sage Handbook of Governance (London: Sage), ch. 23.

Bevir, M. and Rhodes, R. A. W. (2003) Interpreting British Governance (London: Routledge).

Bevir, M. and Rhodes, R. A. W. (2006) Governance Stories (London: Routledge).

Bevir, M. and Rhodes, R. A. W. (2010) The State as Cultural Practice (Oxford: Oxford University Press).

Bevir, M. and Richards, D. (eds) (2009) 'Decentring policy networks', Public Administration, special issue, 88:1, 132-141.

Bevir, M. and Trentmann, F. (eds) (2007) Governance, Consumers, and Citizens: Agency and Resistance in Contemporary Politics (Basingstoke: Palgrave Macmillan).

Bevir, M., Rhodes, R. and Weller, P. (eds) (2003) 'Traditions of governance: History and diversity', Public Administration, special issue, $81: 1,1-17$.

Booth, A. (2010) 'The traditional standpoint of historians': Tradition and the construction of educational identity in late twentieth-century British higher education', Contemporary British History, 24:4, 493509.

Bratburg, O. (2011) 'Ideas, tradition, and norm entrepreneurs: Retracing guiding principles of foreign policy in Blair and Chirac's speeches on Iraq', Review of International Studies, 37:1, 327-348.

Bulley, D. (2009) 'Textualising British politics: Deconstructing the subject of British foreign policy', British Politics, 4:3, 291-314.

Burke, A. (2008) Fear of Security: Australia's Invasion Anxiety (Cambridge: Cambridge University Press).

Campbell, D. (1998) Writing Security: United States Foreign Policy and the Politics of Identity, revised edn. (Minneapolis, MN: University of Minnesota Press).

Carlsnaes, W. (1992) 'The agency-structure problem in foreign policy analysis', International Studies Quarterly, 36:3, 245-270.

Clark, K. and Gains, F. (eds) (2007) 'Constructing delivery: Implementation as an interpretive process', Critical Policy Analysis, special issue, 1 \& 2, 133-138.

Cox, R. W. (1996) 'Social forces, states and world orders: Beyond international relations theory', in R. W. Cox with T. J. Sinclair (ed.), Approaches to World Order (Cambridge: Cambridge University Press), 85-123.

Craig, D. (2006) 'Community well-being strategy and the legacies of the new institutionalism and new public management in third way New Zealand', in L. Bauld, K. Clarke and T. Maltby (eds), Social Policy Review 18: Analysis and Debate in Social Policy (Bristol: Policy Press), 193-220.

Daddow, O. and Gaskarth, J. (eds) (2011) British Foreign Policy: The New Labour Years (Basingstoke and New York: Palgrave Macmillan).

Daddow, O. J. (2004) Britain and Europe since 1945: Historiographical Perspectives on Integration (Manchester: Manchester University Press).

(C) 2012 The Authors. British Journal of Politics and International Relations $\odot 2012$ Political Studies Association BJPIR, 2012 
JOBNAME: No Job Name PAGE: 10 SESS: 10 OUTPUT: Thu Aug 2 19:14:40 2012 SUM: 0A01D76E

/v2501/blackwell/B_journals/bjpi_v0_i0/bjpi_537

Daddow, O. J. (2011) New Labour and the European Union: Blair and Brown's Logic of History (Manchester: Manchester University Press).

Dinham, A. and Lowndes, V. (2008) 'Religion, resources, and representation: Three narratives of faith engagement in British urban governance', Urban Affairs Review, 43:6, 817-845.

Doty, R. L. (1996) Imperial Encounters: The Politics of Representation in North-South Relations (Minneapolis, MN: University of Minnesota Press).

Dudley, G. (2003) 'Ideas, bargaining and flexible policy communities: Policy change and the case of the Oxford transport strategy', Public Administration, 81:3, 433-458.

Dunne, T. (2004) “'When the shooting starts": Atlanticism in British security strategy', International Affairs, 80:5, 893-909.

Edwards, A. (2011) 'Interpreting New Labour's political discourse on the peace process', in K. Hayward and C. O'Donnell (eds), Political Discourse and Conflict Resolution: Debating Peace in Northern Ireland (Abingdon: Routledge), 46-61.

Fierke, K. (2007) Critical Approaches to International Security (Cambridge: Polity).

Finlayson, A. (ed.) (2004) 'The interpretive approach to political science: A symposium', British Journal of Politics and International Relations, 6:2, 129-164.

Finlayson, A. (ed.) (2008) 'Characterizing New Labour: The case of the child trust fund', Public Administration, 86:1, 95-110.

Finnemore, M. and Sikkink, K. (1999) 'International norm dynamics and political change', International Organization, 52:4, 887-917.

Fioretos, O. (2011) 'Historical institutionalism in international relations', International Organization, 65:2, 367-399.

Frankel, J. (1963) The Making of Foreign Policy: An Analysis of Decision-Making (Oxford: Oxford University Press).

George, A. (1969) 'The operational code: A neglected approach to the study of political decision-making', International Studies Quarterly, 13, 190-222.

George, J. and Campbell, D. (1990) 'Patterns of dissent and celebration of difference: Critical social theory and international relations', International Studies Quarterly, 34:3, 269-293.

Goldstein, J. and Keohane, R. O. (eds) (1993) Ideas and Foreign Policy: Beliefs, Institutions and Political Change (Ithaca, NY: Cornell University Press).

Hague, W. (2011) 'The Commonwealth in a networked world', Speech to The Lowy Institute for International Policy, Sydney, Australia, 19 January. Available online at: http://www.lowyinstitute.org/ Publication.asp?pid=1490

Hall, I. (2006) The International Thought of Martin Wight (New York: Palgrave).

Hall, I. (2012) The Dilemmas of Decline: British Intellectuals and World Politics, 1945-1975 (Berkeley, CA: University of California Press GAIA).

Hall, I. (2013) “"Building the global network?” The reform of the foreign and commonwealth office under New Labour', British Journal of Politics and International Relations, $\bullet \bullet: \bullet \bullet-\bullet \bullet$. (forthcoming).

Hall, I. and Rengger, N. (2005) 'The right that failed? The ambiguities of conservative thought and the dilemmas of conservative practice in international affairs', International Affairs, 81:1, 69-82.

Hall, R. B. and Biersteker, T. J. (eds) (2002) The Emergence of Private Authority in Global Governance (Cambridge: Cambridge University Press).

Hermann, M. G. (1980) 'Explaining foreign policy behavior using the personal characteristics of leaders', International Studies Quarterly, 24:1, 7-46.

Holsti, K. J. (1970) 'National role conceptions in the study of foreign policy', International Studies Quarterly, $14,232-309$.

Irazabal, C. (2005) City Making and Urban Governance in the Americas: Curitiba and Portland (London: Ashgate).

Jervis, R. (1976) Perception and Misperception in International Politics (Princeton, NJ: Princeton University Press).

Jones, R. (1974) The Changing Structure of British Foreign Policy (London: Longman).

Jose, J. (2007) 'Reframing the "governance" story', Australian Journal of Political Science, 42:3, 455-470.

Katzenstein, P. (1996a) Cultural Norms and National Security: Police and Military in Post-War Japan (Ithaca, NY: Cornell University Press). 
JOBNAME: No Job Name PAGE: 11 SESS: 10 OUTPUT: Thu Aug 2 19:14:40 2012 SUM: 15E5D4EE /v2501/blackwell/B_journals/bjpi_v0_i0/bjpi_537

Katzenstein, P. (ed.) (1996b) The Culture of National Security: Norms and Identity in World Politics (New York: Columbia University Press).

Keens-Soper, M. (1999) Europe in the World: The Persistence of Power Politics (Houndmills: Macmillan).

Kenny, C. (2010) 'At ideological loggerheads: Identifying and clarifying the discursive differences between Blair and Brown on education', British Politics, 5:3, 367-384.

Keohane, R. O. (1988) 'International institutions: Two approaches', International Studies Quarterly, 32:4, 379-396.

Krueger, R. and Gibbs, D. (2010) 'Competitive global city regions and "sustainable development"', Environment and Planning A, 42:4, 821-837.

Kubalkova, V. (2001) Foreign Policy in a Constructed World (London: M E Sharpe).

Laffey, M. and Weldes, A. J. (1997) 'Beyond belief: Ideas and symbolic technologies in the study of international relations', European Journal of International Relations, 3:2, 193-237.

Larson, D. W. (1994) 'The role of belief systems and schemas in foreign policy decision-making', Political Psychology, 15:1, 17-33.

Marsh, D. (2008) 'Understanding British government: Analysing competing models', British Journal of Politics and International Relations, 10:2, 251-268.

McDonald, M. (2005) 'Constructing insecurity: Australian security discourse and policy post-2001', International Relations, 19:3, 297-320.

Mearsheimer, J. (2001) The Tragedy of Great Power Politics (New York: W. W. Norton).

Monro, S. (2006) 'New institutionalism and sexuality at work in local government', Gender, Work, and Organization, 14:1, 1-19.

Morrell, K. (2006) 'Policy as narrative: New Labour's reform of the national health service', Public Administration, 84:2, 367-385.

Northedge, F. S. (ed.) (1961) British Foreign Policy: The Process of Readjustment, 1945-1961 (London: Allen \& Unwin).

O'Brien, M., Atkinson, A., Burton, D., Campbell, A., Qualter, A. and Varga-Atkins, T. (2009) 'Social inclusion and learning networks: "A wider notion of learning" or taking things in different direction', Research Papers in Education, 24:1, 57-75.

Onuf, N. (1989) World of Our Making: Rule and Rules in Social Theory and International Relations (Columbia, SC: University of South Carolina Press).

Orr, K. (2005) 'Interpreting narratives of local government change under the conservatives and New Labour', British Journal of Politics and International Relations, 7:3, 371-385.

Orr, K. (2009) 'Local government and structural crisis: An interpretive approach', Policy and Politics, 37:1, $39-55$.

Orr, K. and Vince, R. (2009) 'Traditions of local government', Public Administration, 87:3, 655-677.

Reynolds, D. (2000) Britannia Overruled: British Policy and World Power in the Twentieth Century (2nd edn.) (London: Longman).

Rhodes, R., 't Hart, P. and Noordegraaf, M. (eds) (2007) Observing Government Elites: Up Close and Personal (Basingstoke: Palgrave Macmillan).

Richards, D. and Mathers, H. (2010) 'Political memoirs and New Labour: Interpretations of power and the club rules', British Journal of Politics and International Relations, 12:4, 498-522.

Richards, D. and Smith, M. (2004) 'Interpreting the world of political elites', Public Administration, 82:4, $777-800$.

Risse, T., Ropp, S. C. and Sikkink, K. (1999) The Power of Human Rights: International Norms and Domestic Change (Cambridge: Cambridge University Press).

Rose, G. (1998) 'Neoclassical realism and theories of foreign policy', World Politics, 51:1, 144-172.

Sullivan, H. (2007) 'Interpreting "community leadership" in English local government', Policy and Politics, $35: 1,141-162$

Wallerstein, I. (2004) World-Systems Analysis: An Introduction (Durham, NC: Duke University Press).

Walt, S. (1990) The Origins of Alliances (Ithaca, NY: Cornell University Press).

Waltz, K. (1979) Theory of International Politics (Reading, MA: Addison-Wesley).

Weldes, J. (1996) 'Constructing national interests', European Journal of International Relations, 2:3, 275-318.

(1) 2012 The Authors. British Journal of Politics and International Relations () 2012 Political Studies Association BJPIR, 2012 
JOBNAME: No Job Name PAGE: 12 SESS: 10 OUTPUT: Thu Aug 2 19:14:40 2012 SUM: 5ACB05AC /v2501/blackwell/B_journals/bjpi_v0_i0/bjpi_537

Weldes, J. (1999) Constructing National Interests: The United States and the Cuban Missile Crisis (Minneapolis, MN: University of Minnesota Press).

Wendt, A. (1987) 'The agent-structure problem in international relations theory', International Organization, 41:3, 335-370.

Wendt, A. (1992) 'Anarchy is what states make of it: The social construction of power politics', International Organization, 46:2, 391-425.

Wendt, A. (1994) 'Collective identity formation and the international state', American Political Science Review, 88:2, 384-396.

Wendt, A. (1995) 'Constructing international politics', International Security, 20:1, 71-81.

Wendt, A. (1999) Social Theory of International Politics (Cambridge: Cambridge University Press).

Williams, P. D. (2004) 'Who's making UK foreign policy?', International Affairs, 80:5, 909-929.

Wood, J., Fleming, J. and Marks, M. (2008) 'Building the capacity of police change agents: The nexus policing project', Policing and Society, 18:1, 72-87.

Yi-Chong, X. and Weller, P. (2007) 'To be, but not to be seen: Exploring the impact of international civil servants', Public Administration, 86:1, 35-51. 


\section{AUTHOR QUERY FORM}

Dear Author,

During the preparation of your manuscript for publication, the questions listed below have arisen. Please attend to these matters and return this form with your proof.

Many thanks for your assistance.

\begin{tabular}{|l|l|l|}
\hline $\begin{array}{l}\text { Query } \\
\text { References }\end{array}$ & Query & Remarks \\
\hline 1 & $\begin{array}{l}\text { AUTHOR: Stoker 2006 has not been included in the } \\
\text { Reference List, please supply full publication details. }\end{array}$ & \\
\hline 2 & $\begin{array}{l}\text { AUTHOR: A reference has been added for Bevir and } \\
\text { Hall 2011. Please confirm that it is correct. }\end{array}$ & \\
\hline 3 & $\begin{array}{l}\text { AUTHOR: Wallerstein 1974 has been changed to } \\
\text { Wallerstein 2004 so that this citation matches the } \\
\text { Reference List. Please confirm that this is correct. }\end{array}$ & $\begin{array}{l}\text { AUTHOR: Please check this website address and } \\
\text { confirm that it is correct for Hague 2011. (Please } \\
\text { note that it is the responsibility of the author(s) to } \\
\text { ensure that all URLs given in this article are correct } \\
\text { and useable.) }\end{array}$ \\
\hline 5 & $\begin{array}{l}\text { WILEY-BLACKWELL: Please supply the volume } \\
\text { number and page range for Reference Hall 2013. }\end{array}$ & \\
\hline 6 & $\begin{array}{l}\text { AUTHOR: Holsti, 1970 has not been cited in the } \\
\text { text. Please indicate where it should be cited; or } \\
\text { delete from the Reference List. }\end{array}$ & \\
\hline 7 & $\begin{array}{l}\text { AUTHOR: Kubalkova, 2001 has not been cited in the } \\
\text { text. Please indicate where it should be cited; or } \\
\text { delete from the Reference List. }\end{array}$ & \\
\hline
\end{tabular}


Required software to e-Annotate PDFs: Adobe Acrobat Professional or Adobe Reader (version 8.0 or above). (Note that this document uses screenshots from Adobe Reader $\mathrm{X}$ )

The latest version of Acrobat Reader can be downloaded for free at: http://get.adobe.com/reader/

Once you have Acrobat Reader open on your computer, click on the Comment tab at the right of the toolbar:

닙

This will open up a panel down the right side of the document. The majority of tools you will use for annotating your proof will be in the Annotations section, pictured opposite. We've picked out some of these tools below:

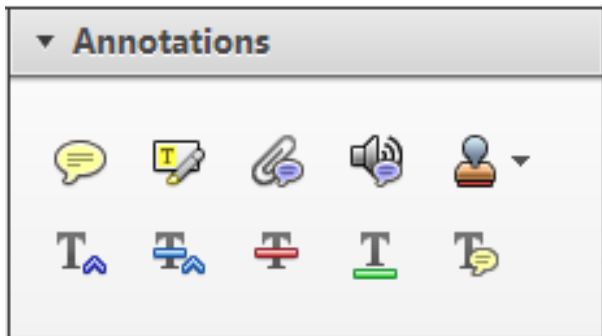

1. Replace (Ins) Tool - for replacing text.

Strikes a line through text and opens up a text box where replacement text can be entered.

\section{How to use it}

- Highlight a word or sentence.

- Click on the Replace (Ins) icon in the Annotations section.

- Type the replacement text into the blue box that appears.

Idard tramework for the analysis of $\mathrm{m}$ icy-Nevertheless, it also led to exog،

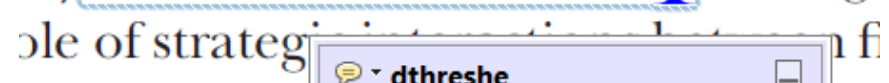
aber of comp 08/06/2011 15:58:17

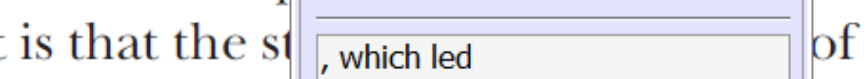
nain compo: be level, are exc nc

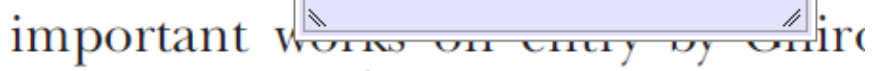
M heneferth) ${ }^{1}$ we anen the 'hlark $\mathrm{h}$

3. Add note to text Tool - for highlighting a section to be changed to bold or italic.

T Highlights text in yellow and opens up a text box where comments can be entered.

\section{How to use it}

- Highlight the relevant section of text.

- Click on the Add note to text icon in the Annotations section.

- Type instruction on what should be changed regarding the text into the yellow box that annears.

namic responses of mark ups ent with the VAR evidence

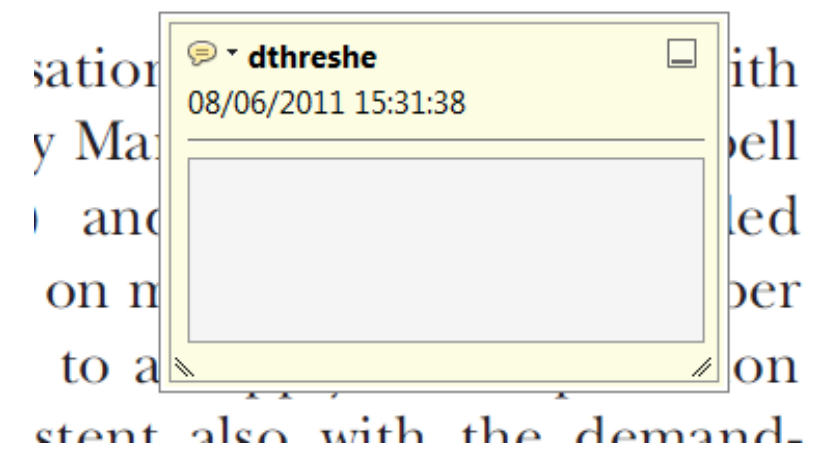

2. Strikethrough (Del) Tool - for deleting text.

Thikes a red line through text that is to be deleted.

\section{How to use it}

- Highlight a word or sentence.

- Click on the Strikethrough (Del) icon in the Annotations section.

there is no room tor extra prohts al c ups are zero and the number of ret) values are not determined by Blanchard and Kiyotaki (1987), rfect competition in general equilil ts of aggregate demand and supply lassical framework assuming monol eon an evorenois number of firms

\section{Add sticky note Tool - for making notes at} specific points in the text.

Marks a point in the proof where a comment needs to be highlighted.

\section{How to use it}

- Click on the Add sticky note icon in the Annotations section.

- Click at the point in the proof where the comment should be inserted.

- Type the comment into the yellow box that appears.

lallu allu suppiy silucks. hivst vi

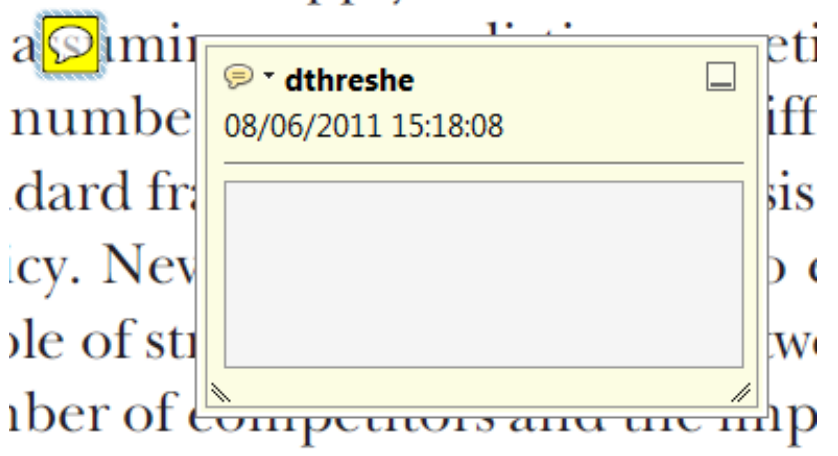

is that the structure of the secto 
5. Attach File Tool - for inserting large amounts of text or replacement figures.

Inserts an icon linking to the attached file in the appropriate pace in the text.

How to use it

- Click on the Attach File icon in the Annotations section.

- Click on the proof to where you'd like the attached file to be linked.

- Select the file to be attached from your computer or network.

- Select the colour and type of icon that will appear in the proof. Click OK.

E N D

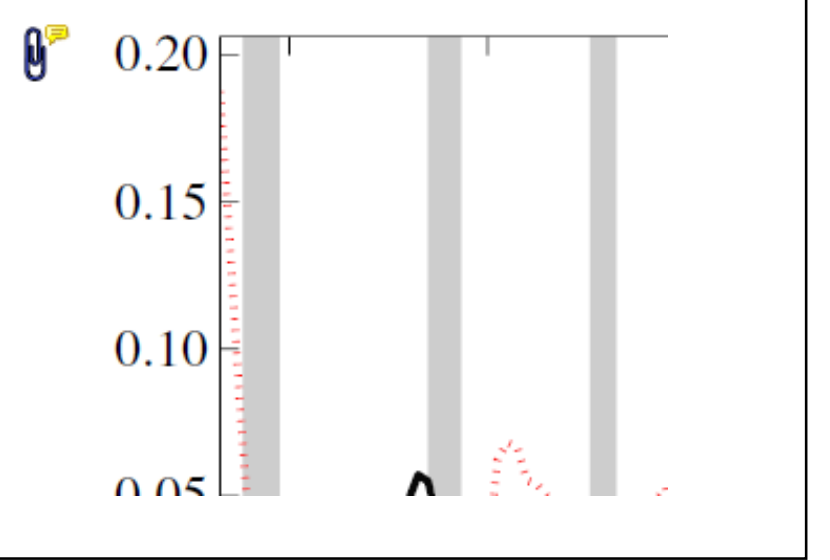

6. Add stamp Tool - for approving a proof if no corrections are required.

- Inserts a selected stamp onto an appropriate place in the proof

\section{How to use it}

- $\quad$ Click on the Add stamp icon in the Annotations section.

- $\quad$ Select the stamp you want to use. (The Approved stamp is usually available directly in the menu that appears).

- Click on the proof where you'd like the stamp to appear. (Where a proof is to be approved as it is, this would normally be on the first page).

of the Dusiness cycie, starting with the on perfect competition, constant ret

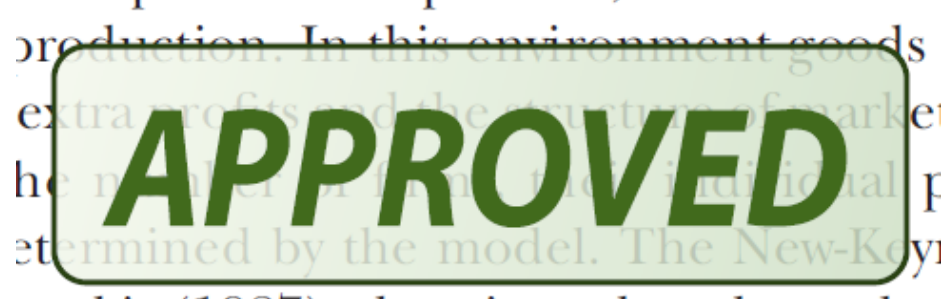

otaki (1987), has introduced produc general equilibrium models with nomin
- Drawing Markups

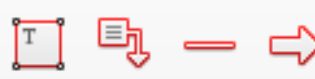

$0 \square \sqrt{6} D$

\section{How to use it}

- Click on one of the shapes in the Drawing Markups section.

- Click on the proof at the relevant point and draw the selected shape with the cursor.

- To add a comment to the drawn shape, move the cursor over the shape until an arrowhead appears.

- Double click on the shape and type any text in the red box that appears.
7. Drawing Markups Tools - for drawing shapes, lines and freeform annotations on proofs and commenting on these marks.

Allows shapes, lines and freeform annotations to be drawn on proofs and for comment to be made on these marks.

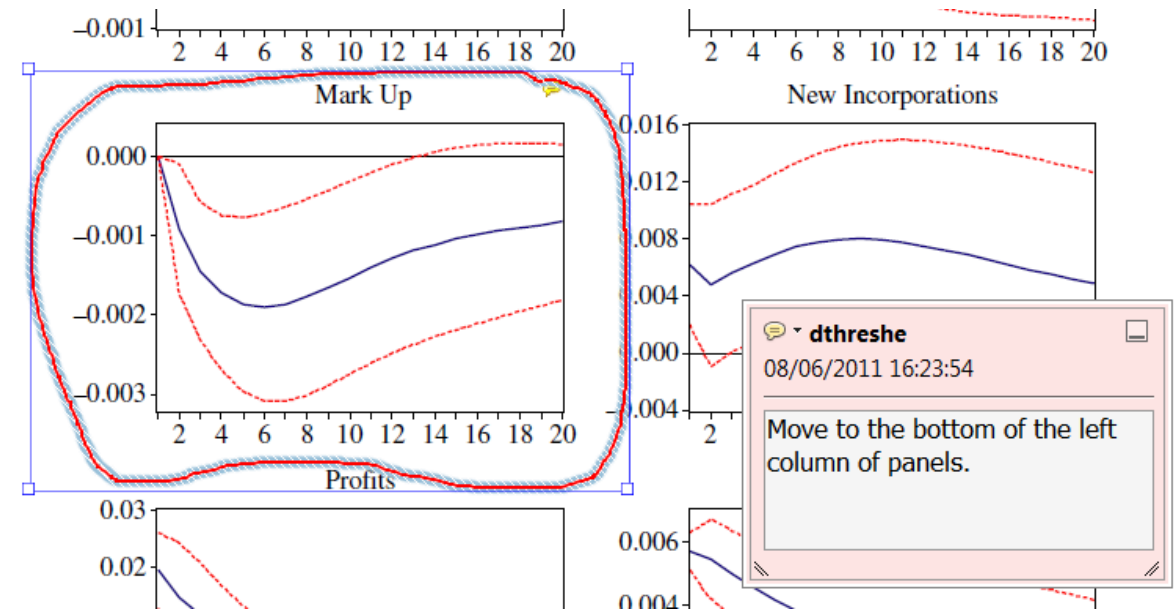

For further information on how to annotate proofs, click on the Help menu to reveal a list of further options:

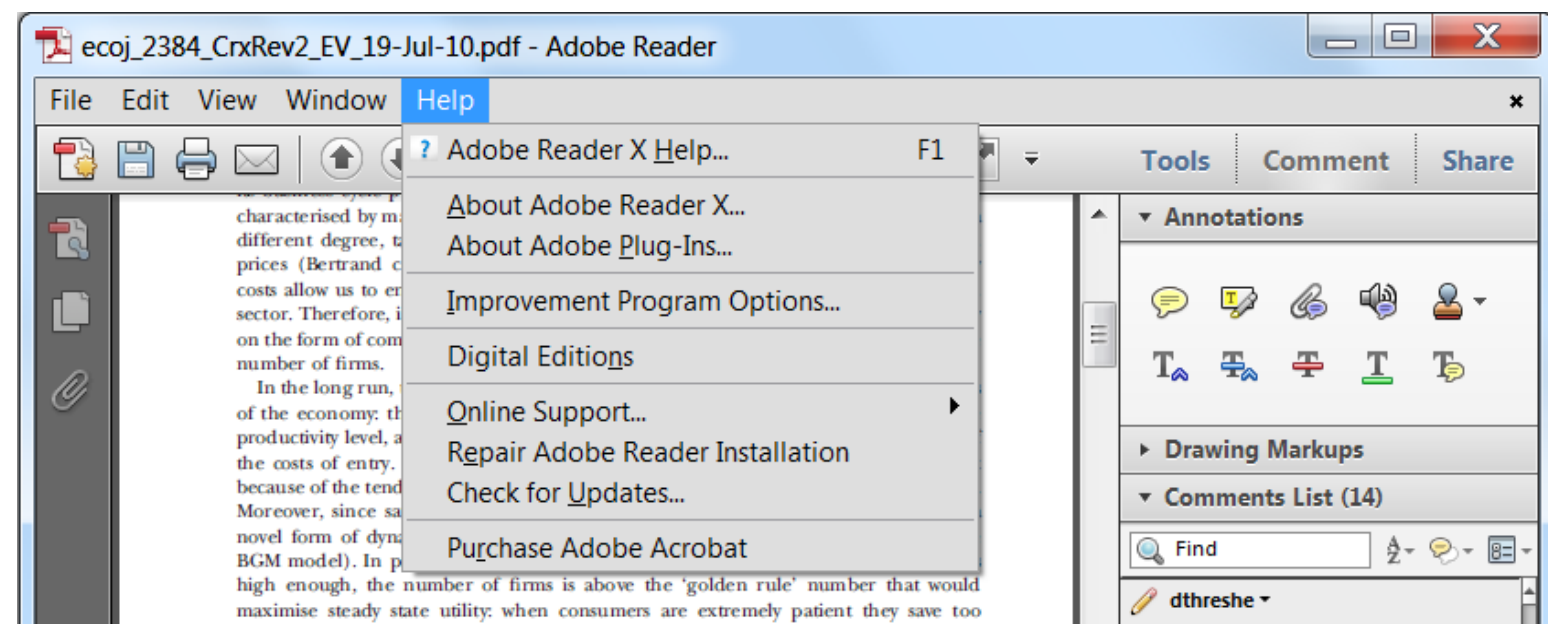

